\title{
EDITORIAL
}

\section{Protecting the Tangible and Intangible Values of Transnational Environmental Spaces}

\section{INTRODUCTION}

Environmental policy and law walk a tightrope between preserving present and future environmental resources while allowing for their exploitation in the interest of socio-economic development. This raises fundamental and complex questions regarding the weight to be given to current and future economic gain, environmental protection, and the interests of different peoples affected by this interplay. At the transnational level, these challenges are compounded by the absence of clear and targeted political accountability for any trade-offs struck by an increasingly diversified range of decision makers operating at different scales of government. Depending on one's views regarding the balance between environmental exploitation and protection, this may be considered a very positive development; the rise of new actors within transnational environmental law means greater possibility for inclusion, representation and legitimacy. Moreover, it provides alternatives to processes that may have stalled as a result of political inertia or stand-offs at the national or international level. However, accommodating these processes within the existing legal and political framework presents its own difficulties.

As transnational environmental law matures, our thoughts on these issues, and the processes that accompany them, continue to evolve accordingly. In this issue of TEL, two different ways of thinking about, and addressing, this changing reality and its challenges for the protection of the environment are presented. The first three articles - by Louis Kotzé; Herdis Hølleland, Evan Hamman and Jessica Phelps; and Benjamin Richardson, Emily Barritt and Megan Bowman - consider value systems that can assist in conceptualizing legal protection in a transnational environment. The first two of these articles focus on existing, but arguably under-used, international agreements, while the third explores the potential of the concept of 'beauty' in creating a global language for environmental law. The second set of contributions - by Joseph Wenta, Jan McDonald and Jeffrey McGee; Prischa Listiningrum; Jerneja Penca; and Benoit Mayer - maps out specific legal avenues towards ensuring justice and redress for groups who are casualties in the balancing act between environmental exploitation and protection, as well as creative strategies of empowerment by local groups in a transnational environment. The role of transnational environmental law comes to the fore in each contribution through the challenges, as well as the opportunities, in 
finding and maintaining a shared set of values while accommodating a changing group of increasingly versatile protagonists in a transnational context.

\section{CONSTITUTIONALISM, WORLD HERITAGE, AND BEAUTY: LEGALIZING VALUES}

The way in which one decides to approach the fundamental questions that underlie the balance between environmental protection and exploitation depends on the values that one assigns to environmental and human well-being, and how one sees their interaction. In 'A Global Environmental Constitution for the Anthropocene?', Louis Kotzé emphasizes the moment of socio-ecological crisis that the world faces and the failures of international environmental law (IEL) in addressing it. ${ }^{1}$ These shortcomings, as well as the multiple causes and effects of these failings, are well documented. ${ }^{2}$ Within this plurality of problems, Kotzé identifies the root cause as the absence of a 'core set of fundamental values that binds states'. ${ }^{3}$ Together with the observation that IEL was developed and based on principles more appropriate for the Holocene than the Anthropocene, Kotzé concludes that the creation of a global environmental constitution is critical for the development of effective IEL.

While Kotzé is not the first to propose this strategy, his contribution comes at a crucial time. The United Nations (UN)-backed initiative for a Global Pact for the Environment, introduced in $2017,{ }^{4}$ could make a global environmental constitution a reality. This binding legal instrument aims to create a universal right to a sound environment, which may be invoked as a human right at the international, national, and regional levels. ${ }^{5}$ Despite these hopeful developments, Kotzé is critical of the anthropocentric focus of the Pact, ${ }^{6}$ which is, inter alia, evident in the use of human rights as a delivery system for environmental protection and balance. ${ }^{7}$ This human right is combined with a duty of care for the environment, which extends to non-state actors, including legal and natural persons - a provision which echoes developments highlighted by Benoit Mayer ${ }^{8}$ and Prischa Listiningrum ${ }^{9}$ in this issue, but nevertheless represents a legal innovation under IEL.

\footnotetext{
L. Kotzé, 'A Global Environmental Constitution for the Anthropocene?' (2019) 8(1) Transnational Environmental Law, pp. 11-33, at 11-13.

2 Also detailed in Kotzé, ibid., p. 16.

3 Ibid., p. 17. See also D. Bodansky, 'Is There an International Environmental Constitution?' (2009) 16 (2) Indiana Journal of Global Legal Studies, pp. 565-84, at 579-80.

4 Global Pact for the Environment, Paris (France), 24 June 2017, available at: https://www.iucn.org/sites/ $\mathrm{dev} /$ files/content/documents/draft-project-of-the-global-pact-for-the-environment.pdf; see also the Pact's dedicated website: https://globalpactenvironment.org.

5 See also the mandate of the working groups established under the UNGA Resolution 72/277 'Towards a Global Pact for the Environment' (10 May 2018), UN Doc. A/RES/72/277, available at: https://www.un.org/en/ga/search/view_doc.asp?symbol=A/RES/72/277.

6 Kotzé, n. 1 above, pp. 14, 25.

7 Global Pact, n. 4 above, Art. 1.

8 Mayer, n. 44 below.

9 Listiningrum, n. 40 below.
} 
Kotzé suggests that in order to ensure that the Global Pact achieves its potential to reform IEL, lessons must be learned from the World Charter for Nature. The Charter was adopted by the UN General Assembly in 1982 and espouses a more ecocentric approach than the Pact so far displays. ${ }^{10}$ As such, it is argued that the World Charter is the closest example of environmental constitutionalism within IEL, ${ }^{11}$ and an important blueprint for a Global Pact capable of achieving the type of fundamental changes to IEL that Kotzé considers necessary. ${ }^{12}$ The eventual consequences of these changes remain uncertain and will be hard to verify in the absence of a counterfactual; academics have been relatively more successful at identifying failures ex post than ensuring the design or implementation of 'winners'.

In support of the latter, the empirical study by Herdis Hølleland, Evan Hamman and Jessica Phelps sheds light on the practice of implementation of an important instrument of IEL, ${ }^{13}$ namely, the 1972 Convention concerning the Protection of the World Cultural and Natural Heritage (WHC). ${ }^{14}$ The Convention provides for the use of a compliance mechanism in the form of the List of World Heritage in Danger. The List features sites that are considered 'in danger' by the World Heritage Committee. ${ }^{15}$ Placement of a site on the List has a dual function in so far as it draws attention to the fact that a site is at risk, of either actual or potential dangers, and it can act as a 'naming and shaming' device by highlighting the failure of states to comply with their obligations under the WHC.

Although not the authors' main focus, it is interesting to compare the criteria for endangerment under the WHC with the constitutionalist approach advocated by Kotzé. The three most common reasons for inclusion on the List are war, unrest, and human-led developments in or around a World Heritage site. ${ }^{16}$ Analysis of the use of the List shows that states are unlikely to request a listing in the case of potentially or actually dangerous human-led development, whereas state-initiated listings caused by war or unrest are relatively common. ${ }^{17}$ Predictably, this suggests that any international consensus on the importance of environmental protection suffers when pitted against development aims. This could be said to support the need for a statement of global environmental values, while underlining Kotzés concern in framing these values in an anthropocentric way.

As an example of transnational regulation, the 'fire alarm' function of the List of World Heritage in Danger ${ }^{18}$ of alerting state and non-state actors to the

10 UNGA Resolution 37/7, 'World Charter for Nature' (28 Oct. 1982), UN Doc. A/RES/37/7, available at: http://www.un.org/documents/ga/res/37/a37r007.htm.

11 Kotzé, n. 1 above, p. 31.

12 Ibid., p. 33.

13 H. Hølleland, E. Hamman \& J. Phelps, 'Naming, Shaming and Fire Alarms: The Compilation, Development and Use of the List of World Heritage in Danger' (2019) 8(1) Transnational Environmental Law, pp. 35-57.

14 Paris (France), 16 Nov. 1972, in force 17 Dec. 1975, available at: http://whc.unesco.org/archive/ convention-en.pdf or http://whc.unesco.org/en/conventiontext.

15 Hølleland, Hamman \& Phelps, n. 13 above, p. 37.

16 Ibid., p. 48.

17 Ibid., p. 49.

18 Ibid., p. 52. 
endangerment of certain sites shows a particularly effective example of transnational regulation in so far as listing sites legitimizes the involvement of non-state actors in their protection. ${ }^{19}$ Moreover, it imposes a moral obligation on other state actors to assist the home state of the endangered site. ${ }^{20}$ However, the authors also find that using the List in this fashion is neither without cost nor instantaneous, and more effective means of achieving the same goals may be imagined. ${ }^{21}$ In terms of the disciplinary effect of listing, the authors find that it is harder to predict whether states will actually respond to the 'naming and shaming' effect and that much depends on local dynamics and politics. ${ }^{22}$ Importantly, the authors' empirical quantitative analysis draws attention to the main reasons for listing, though the reasons for compliance with protection obligations depend on a qualitative study which is yet to be undertaken. The authors suggest that such a study would have to focus more narrowly on the details of each individual site, both listed and ultimately not listed, ${ }^{23}$ showing the importance of local conditions in transnational processes.

The suggestion that local factors can be determinative in environmental protection decisions can be contrasted with the idea of global environmental constitutionalism, and with the efforts of Benjamin Richardson, Emily Barritt and Megan Bowman to introduce beauty as the basis for a common understanding of environmental impacts. ${ }^{24}$ In 'Beauty: A Lingua Franca for Environmental Law?' the authors point out that, although difficult to capture as a legal concept, natural law demands that beauty be legally protected and nurtured, as one of the seven basic goods that give value to human lives. ${ }^{25}$ Significantly, the authors juxtapose the process of aesthetic valuation with those underlying economics and science, which are mainstream in environmental law, literature, and policy, ${ }^{26}$ in much the same way as Kotzé contrasts global environmental constitutionalism with neoliberal anthropocentrism present in IEL. ${ }^{27}$ However, aesthetic appreciation of nature remains intrinsically anthropocentric as beauty is still 'in the eye of the beholder'. Moreover, humans appear drawn not only to the beauty of prospering environments but also to that resulting from ecological devastation and the killing of animals and plants. ${ }^{28}$ This, and other methodological challenges, form part of the explanation of why beauty is currently not part of environmental law in the way the authors advocate. ${ }^{29}$

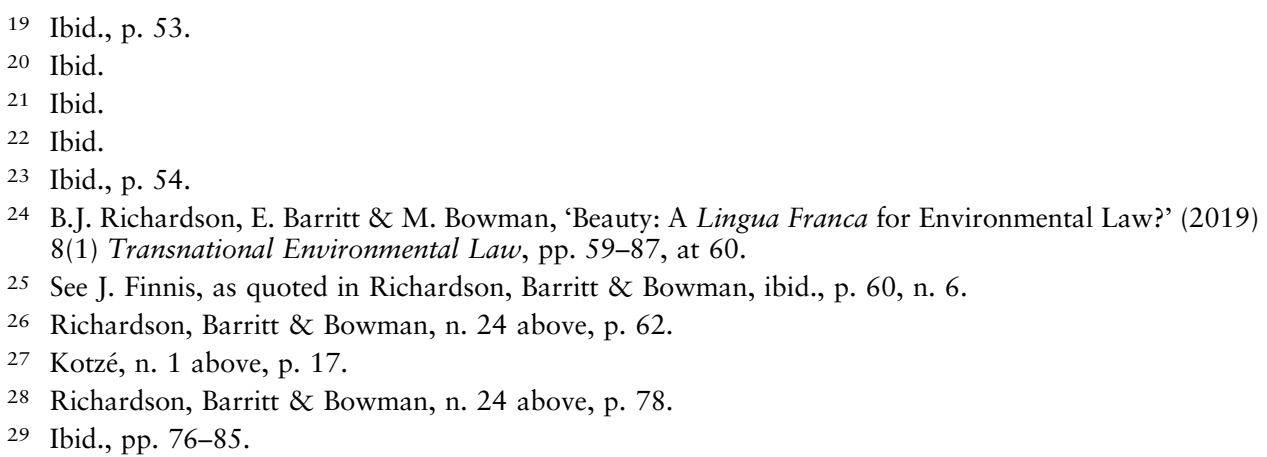


Ultimately, Richardson, Barritt and Bowman stop short of suggesting that beauty can, or should be, the lingua franca of environmental law in all contexts. Such a development might be particularly problematic at the global level, which is especially relevant for transnational environmental law. ${ }^{30}$ However, the language and tools of aesthetics (namely, the expression of beauty through art) may play a productive role in helping us to bridge the language gaps between law, science, economics, and other fields relevant to environmental law. ${ }^{31}$ It is suggested that beauty will not become a legal standard or concept but could be a way to stimulate a process of appreciating nature, as well as a way to encourage relationships with our environment. ${ }^{32}$

The contributions that constitute the first part of this issue show that in protecting environmental values, part of the challenge is to identify them and find a common language to discuss them. The empirical analysis of World Heritage protection underlines the limits of any such shared language and highlights the continued importance of local processes and preferences in the implementation of global frameworks. The second part of this issue delves deeper into the dualist global-local challenge through several case studies that examine various legal strategies to manage deleterious environmental impacts.

\section{JUSTICE, RESILIENCE AND EMPOWERMENT IN GLOBAL AND LOCAL CONTEXTS}

Notwithstanding the efforts to halt, or even reverse, some of the effects of the current environmental crisis, we have reached a point where serious policy and scholarly energy must be dedicated to adaptation. Different from mitigation, adaptation is an almost exclusively anthropocentric process as it seeks to diminish the negative impacts of climatic change on humans. ${ }^{33}$ The need to adapt varies widely, based on geography and, more generally, on the vulnerability of certain groups to specific types of environmental impact. ${ }^{34}$ This variation not only notoriously complicates global decision making on climate change mitigation, but also exposes local environmental decisions on zoning polluting activities to the risk of capture by politically and economically powerful groups. In 'Enhancing Resilience and Justice in Climate Adaptation Laws', Joseph Wenta, Jan McDonald and Jeffrey McGee seek to integrate distributive justice concerns within the regulatory science of successful mitigation planning - also known as 'resilience thinking' - in order to move towards climate adaptation laws that promote both resilience and justice. ${ }^{35}$ Similar to adaptation,

30 Ibid., p. 83.

31 Ibid., p. 84.

32 Ibid., p. 87.

33 Adaptation may have beneficial side effects on the non-human environment, but this is traditionally not the focus of adaptation efforts.

34 L. Berrang-Ford et al., 'What Drives National Adaptation? A Global Assessment' (2014) 124(1-2) Climatic Change, pp. 441-50, at 448.

35 J. Wenta, J. McDonald \& J.S. McGee, 'Enhancing Resilience and Justice in Climate Adaptation Laws' (2019) 8(1) Transnational Environmental Law, pp. 89-118. 
environmental justice is a human-centric concept, focusing on how humans experience environmental hazards and benefits. ${ }^{36}$

The analysis by Wenta, McDonald and McGee shows that, while law is central to adaptation, some legal concepts can restrict and even undermine adaptation efforts and environmental justice aims. ${ }^{37}$ Their proposed design principles for climate adaptation laws provide that the possibility of change and the distributive effects of climate change must be acknowledged and considered in legal drafting. Moreover, participation in the adaptation process is to be promoted. Finally, the law must be able to cross sectors and scales. As recognized by the authors, a key challenge in operationalizing these principles is that the substance of adaptation laws tends to depend on a highly localized set of conditions, which makes further case studies necessary, and the upscaling of adaptation laws difficult. ${ }^{38}$ The articles by Prischa Listiningrum and Jerneja Penca provide valuable examples of such case studies, focusing on access to justice and the upscaling of local efforts respectively.

In light of the irreversible damage caused by certain types of environmental impact, the desirability of using legal instruments to prevent certain impacts is selfevident. Much of national and international environmental law aims to do just this by setting standards and regulating activities. In addition, the law can be used to impose liability on parties - both private and public - for damage caused by negligent or criminal acts. The strengths and weaknesses of preventative and remedial legal action have been widely discussed, as has the relative suitability of regulators, courts and private actors in determining the 'optimal' type and level of environmentally damaging behaviour. ${ }^{39}$ That said, the types of actor combined with the types of act and the nature of the damage caused with respect to environmental regulation can complicate normally straightforward processes of redress and reparation.

In 'Transboundary Civil Litigation for Victims of Southeast Asian Haze Pollution: Access to Justice and the Non-Discrimination Principle', Listiningrum provides a case study of the obstacles to access to justice in civil litigation regarding damage caused by haze pollution, which identifies the gaps that remain in enabling victims to hold parties responsible and receive compensation. ${ }^{40}$ Apart from problems of causation, the availability of remedies and potential immunities, the Southeast Asian haze pollution case shows that the transboundary nature of the harm can raise important questions of jurisdiction in both the affected countries and the source country. ${ }^{41}$ These problems are particularly pressing since international (environmental) law, as secured through the International Court of Justice (ICJ), faces its own problems of

36 For an introduction to ecological justice, see B. Baxter, A Theory of Environmental Justice (Routledge, 2005), pp. 7-8, cited in Wenta, McDonald \& McGee, ibid., p. 99, n. 83.

37 Wenta, McDonald \& McGee, n. 35 above, pp. 90, 103.

38 Ibid., p. 117.

39 See J. van Zeben, 'A Law and Economics Perspective on Judicial Risk Regulation' (2018) 9(1) European Journal of Risk Regulation, pp. 79-98.

40 P. Listiningrum, 'Transboundary Civil Litigation for Victims of Southeast Asian Haze Pollution: Access to Justice and the Non-Discrimination Principle' (2019) 8(1) Transnational Environmental Law, pp. 119-42.

41 Ibid., p. 138. 
jurisdiction, enforcement, and international politics. ${ }^{42}$ Listiningrum's analysis shows some cause for optimism in so far as bringing a civil claim before an Indonesian court is facilitated by the application of strict liability for pollution in Indonesian tort law. ${ }^{43}$ While this leaves open the bigger question as to the effectiveness of civil tort claims as a deterrent device for future environmentally damaging behaviour, it is a hopeful sign for individual victims of haze pollution in Indonesia.

The issue of civil litigation in pursuit of environmental protection is also the focus of Benoit Mayer's reflections on the recent Court of Appeal decision in the Urgenda case in the Netherlands. ${ }^{44}$ In 2015, the court of first instance ruled that, when interpreting the state's duty of care under Dutch tort law, the government's international obligations need to be taken into account, ${ }^{45}$ including the 'no harm' principle of international law and measures taken as a European Union (EU) Member State. The ruling was considered a victory for environmentalists, exposing the Dutch government to tort liability for its perceived failure to adopt sufficiently ambitious climate change mitigation policies. ${ }^{46}$ However, the ruling was highly controversial, raising concerns regarding its impact on the separation of powers (should a court be prescribing climate policy?) and the role of climate science (are courts equipped to translate the technical information available into legal standards?). ${ }^{47}$

The ruling led to political renegotiations of Dutch climate policy as well as to an appeal by the Dutch government. The appeal, which was expected to rein in the alleged judicial activism of the first ruling, ${ }^{48}$ upheld the initial judgment, expanding the legal grounds for the state's liability with reference to the European Convention on Human Rights and Fundamental Freedoms (ECHR). ${ }^{49}$ The latter is particularly relevant for transnational environmental law as the Court's ECHR-related reasoning could easily be replicated elsewhere. ${ }^{50}$ This potentially increases the ability of the judgment to act as a blueprint for similar ongoing litigation in other jurisdictions. ${ }^{51}$

42 Ibid., p. 140.

43 Ibid., p. 141.

44 B. Mayer, 'Case Note: The State of the Netherlands v. Urgenda Foundation, Ruling of the Court of Appeal of The Hague (9 October 2018)' (2019) 8(1) Transnational Environmental Law, pp. 167-92.

45 M. Loth, 'Too Big to Trail? Lessons from the Urgenda Case' (2018) 23(2) Uniform Law Review, pp. 336-53; E. Stein \& A.G. Castermans, 'Urgenda v. The State of the Netherlands: The Reflex Effect Climate Change, Human Rights, and the Expanding Definitions of the Duty of Care' (2017) 13(2) McGill Journal of Sustainable Development Law, pp. 303-24.

46 An interesting parallel may be drawn here with the Global Pact discussed by Kotzé in this issue, n. 1 above, p. 27. See specifically Art. 15 of the Global Pact, which provides that states must adopt effective environmental laws.

47 See J. van Zeben, 'Establishing a Governmental Duty of Care for Climate Change Mitigation: Will Urgenda Turn the Tide?' (2015) 4(2) Transnational Environmental Law, pp. 339-57. See also J. Peel \& H.M. Osofsky, 'A Rights Turn in Climate Change Litigation?' (2018) 7(1) Transnational Environmental Law, pp. 37-67.

48 See, e.g., O. van Geel, 'Urgenda and Beyond: The Past, Present and Future of Climate Change Public Interest Litigation' (2017) (3) Maastricht University Journal of Sustainability Studies, pp. 56-72.

49 Mayer, n. 44 above, p. 173.

50 Ibid., p. 168.

51 For more general restrictions and complications in terms of the replicability of this judgment, see Van Zeben, n. 47 above. 
Improving access to justice and the ability of the law - and the court as its enforcer - to respond to the challenges that transboundary environmental impacts present is one way in which law can serve as a means of empowerment. Jerneja Penca's article, 'Transnational Localism: Empowerment through Standard Setting in Small-Scale Fisheries', provides a case study of pioneering efforts by local actors to engage with transnational structures as a means to protect and strengthen local strategies of natural resource management. ${ }^{52}$ Moreover, the ability of small-scale fisheries to set their own standards and develop other management and marketing strategies fosters a degree of empowerment and representation in transnational legal processes that is absent from the traditional workings of law. ${ }^{53}$ Nevertheless, the local fisheries' initiatives studied by Penca have been able to thrive partially as a result of the presence of strong governance structures in Europe and North America. ${ }^{54}$ Returning to the theme of adaptability and resilience as raised by Wenta, McDonald and $\mathrm{McGee},{ }^{55}$ the development of transnational law - and a broader conception of what constitutes 'law' - therefore depends at least in part on the ability of existing legal frameworks to adapt to changing legal and social environments. As Penca rightly points out, transnational law provides a starting point for theorizing these new developments, ${ }^{56}$ but empirical studies such as hers provide essential feedback in the process of creating a more complete theory.

\section{CONCLUSION}

The development of transnational environmental law as a discipline in many ways reflects a break with establishment. Academics reflect on the new ways in which law is created, shaped and expressed by a growing range of actors. However, as the contributions to this issue show, this break is by no means absolute or 'clean'. As new processes develop, our reliance on existing concepts and strategies continues. Some have argued that the continued use of familiar tropes comes at the cost of moving the field - how does one think outside the box if it is the only shape that is referenced? However, for those living the reality of environmental impacts, building on established methods for redress, justice and empowerment is a necessary, and valuable, interim step.

The case studies in this issue are a particularly powerful reminder that our focus on what is novel about transnational environmental law should not lead us to ignore continuing ties, such as those to place. Territoriality continues to be a vital part of lawmaking, including for those processes that we have come to consider as part of transnational law. Does this mean that we cannot, or should not, strive towards globalized values or languages such as those advocated in global environmental constitutionalism or a lingua franca based on beauty? As demonstrated by the

52 J. Penca, 'Transnational Localism: Empowerment through Standard Setting in Small-Scale Fisheries' (2019) 8(1) Transnational Environmental Law, pp. 143-65.

53 Ibid., pp. 156-7.

54 Ibid., p. 150.

55 Wenta, McDonald \& McGee, n. 35 above.

56 Penca, n. 52 above, pp. 157-8. 
collection of views in this issue of TEL, transnational environmental law appears capable of incorporating both the local and the global, and the many scales in between. The challenge will be to ensure that the theorization of developments at all scales is considered within the same analytical space, rather than in separate spheres. Identifying, and protecting, the tangible and intangible values of our transnational environment can offer a path towards this - provided this also accommodates regional and local variations. A fresh challenge for a new year.

\section{TEL EDITORIAL BOARD DEVELOPMENTS}

As TEL enters its eighth year in print, the time has come to announce two important changes to our Editorial Board. Exactly nine years ago, we were delighted and honoured that Dan Farber agreed to join the Editorial Board at the time of TEL's launch. Dan's contributions to the journal's growth and success, and his support for us as Editors-in-Chief from TEL's inception stage, are hard to overstate. It is therefore with sadness and sincere gratitude that we say goodbye to Dan, but we are reassured that he will remain a close member of the TEL family, as he joins our Advisory Board.

With such great footsteps to fill, we feel privileged to have found a truly formidable new Editor in Jacqueline Peel, of the University of Melbourne (Australia). Jacqueline has been a recurring contributor to and an active supporter of TEL from its very first issue. She has been a frequent reviewer and she judged and introduced the article competition for TEL's fifth anniversary issue. ${ }^{57}$ We very much look forward to this new phase in our partnership, and to many more years of fruitful collaboration.

Editors-in-Chief

Thijs Etty

Veerle Heyvaert

Editors

Cinnamon Carlarne

Bruce Huber

Jacqueline Peel

Josephine van Zeben

57 J. Peel, Foreword to the TEL Fifth Anniversary Issue 'Re-evaluating the Principle of Common But Differentiated Responsibilities in Transnational Climate Change Law' (2016) 5(2) Transnational Environmental Law, pp. 245-54. 